\title{
Exciplex electroluminescence spectra of the new organic materials based on zinc complexes of sulphanylamino-substituted ligands
}

\author{
S.L.Nikitenko, S.S.Krasnikova, M.G.Kaplunov, I.K.Yakushchenko \\ Institute of Problems of Chemical Physics, Russian Academy of Sciences, \\ 1 Ac.N.Semenov ave., 142432 Moscow region, Chernogolovka, Russia
}

Received November 23, 2011

\begin{abstract}
Electroluminescence spectra of the devices based on the new zinc complexes of aminosubstituted benzothiazoles and quinolines containing $\mathrm{C}-\mathrm{N}-\mathrm{M}-\mathrm{N}$ chains in their chelate cycles have been investigated. The obtained spectra exhibit strong exciplex bands in green-yellow region 540-590 $\mathrm{nm}$ due to interaction of the excited states of zinc complexes and triarylamine molecules of hole-transporting layer. For some devices the intrinsic luminescence band in blue region $460 \mathrm{~nm}$ is also observed along with the exciplex band that results in almost white color of the device emission. The exciplex band can be eliminated if the material of the hole-transporting layer is not triarylamine derivative.
\end{abstract}

\begin{abstract}
Исследованы спектры электролюминесцентных устройств, основанных на новых комплексах цинка амино-замещенных бензотиазолов и хинолинов содержащих $\mathrm{C}-\mathrm{N}-\mathrm{M}-\mathrm{N}$ цепи в их хелатных циклах. Обнаружены сильные эксиплексные полосы в желто-зеленой области 540-590 нм при взаимодействии возбужденных состояний комплекса цинка и молекулы триариламина дырочно-транспортного слоя. Для некоторых устройств, кроме эксиплексной полосы, наблюдается собственная полоса люминесценции в области 460 нм, что приводит к почти белому цвету излучения устройства. Эксиплексная полоса может быть убрана, если материал дырочно-транспортного слоя не является производным триариламина.
\end{abstract}

\section{Introduction}

In typical organic light emitting devices (OLEDs) light originates from radiative relaxation of molecular excited states formed by electrons and holes injected from electrodes and localized on individual molecular sites. The phenomenon is interpreted as due to Frenkel exciton generation and recombination [1, 2]. In particular, this is applied to the bilayer OLEDs composed of metal 8-hydroxyquinolates $\mathrm{Mq}_{3}$ $(\mathrm{M}=\mathrm{Al}, \mathrm{Ga}, \mathrm{In}$, or Sc) as an electron-transporting and emitting layer and amines like TPD as a hole-transporting layer. The electroluminescence (EL) spectra of these devices are close to the photoluminescence (PL) spectra of corresponding $\mathrm{Mq}_{3}$ molecules
[1-3]. The similarity of the EL and PL spectra was also observed for zinc complexes with hydroxy-substituted quinolines, benzothiazoles, oxadiazoles and related ligands [4-6].

In some bilayer devices, interactions of donor and acceptor molecules at the organic/organic interface can lead to formation of an exciplex state. Exciplex is a kind of excited state complex formed between donor and acceptor, with one in the excited state and the other one in the ground state. Exciplex usually leads to the red shifted emission and broadened spectrum relative to the emissions of the individual acceptor or donor [7-10]. Exciplex formation at the interface between $\mathrm{Al}_{3}$ and the electron-rich 

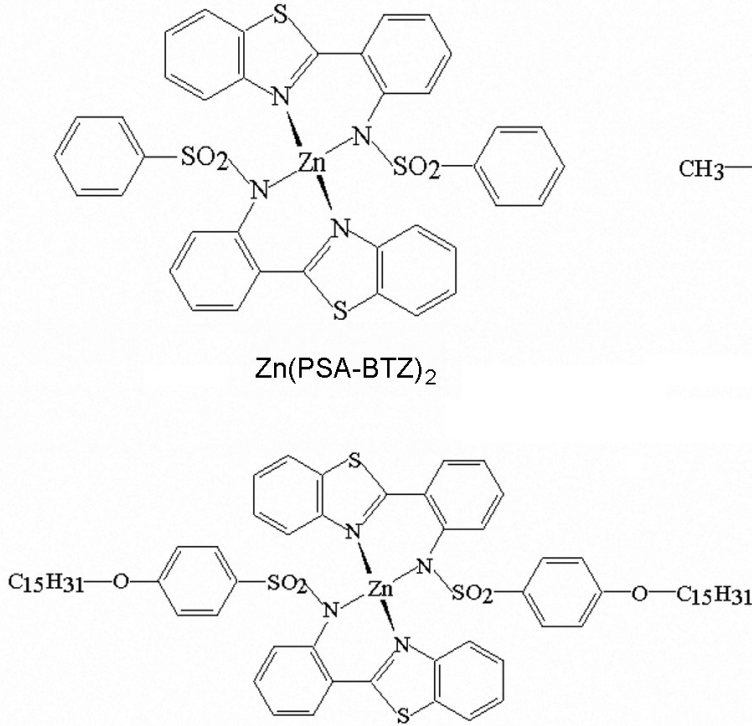

$\mathrm{Zn}(\mathrm{POPS}-\mathrm{BTZ})_{2}$

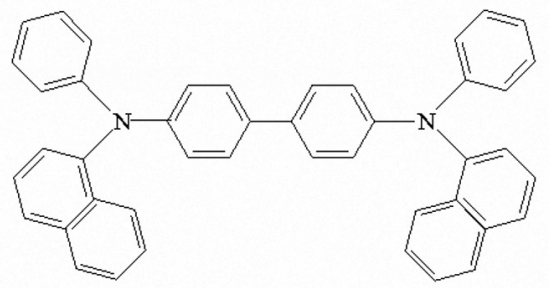

NPD

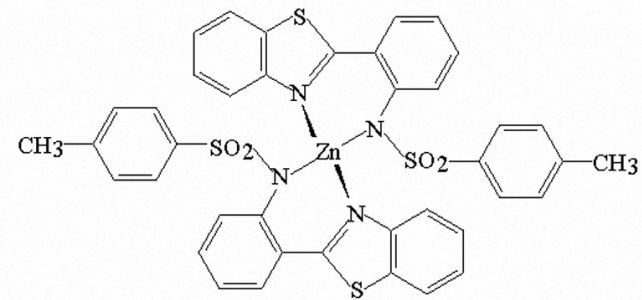

$\mathrm{Zn}(\mathrm{TSA}-\mathrm{BTZ})_{2}$

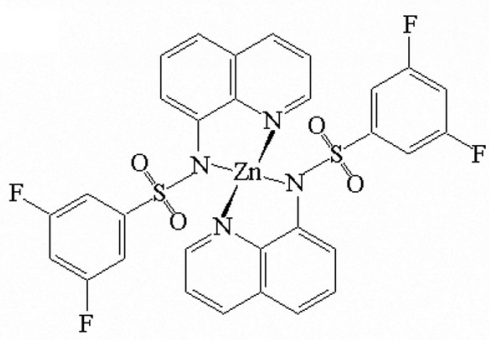

$\mathrm{Zn}(\mathrm{DFP}-\mathrm{SAMQ})_{2}$<smiles>Cc1ccc(N(c2ccc(C)cc2)c2ccc(C(C)C)cc2)cc1</smiles>

$\operatorname{PTA}(\mathrm{n}=8-9)$

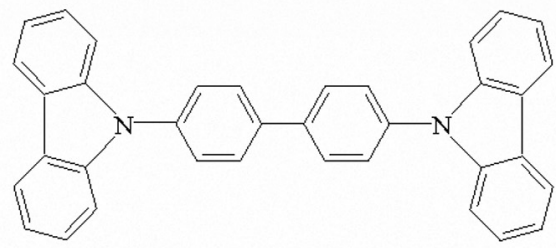

CBP

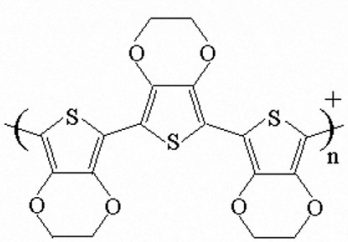<smiles>CCCc1ccc(S(=O)(=O)O)cc1</smiles><smiles>CC(C)c1ccc(S(=O)(=O)O)cc1</smiles>

PEDOT:PSS

Fig. 1. Structures of zinc complexes and materials for hole-transporting layers.

multiple triarylamine hole-transporting materials $m$-MTDATA and $t$-Bu-TBATA was observed in the work [11].

For pure homochromatic OLEDs exciplexes should be avoided [10,12,13]. On the other hand, exciplexes were proposed to design white OLEDs and to tune the OLED emission color [7, 14-17]. One of the problems of utilizing the exciplex effects in devices is to find systems with high exciplex EL efficiency, so design of new materials and investigation of active factors for efficient exciplex emission is a subject of significance.
In the present work we have investigated spectral properties of the electroluminescent devices based on the novel zinc-chelate complexes of sulphanylamino-substituted quinolines and benzothiazoles [18-21]. The structures of zinc complexes are shown in Fig. 1. Most of presently known metal complexes used for OLEDs contain chelate cycles including $\mathrm{C}-\mathrm{O}-\mathrm{M}-\mathrm{N}$ chains $[1-6,9-11]$. In the complexes studied here oxygen atom in the chelate cycles is replaced by nitrogen atom of sulphanylamino groups forming $\mathrm{C}-\mathrm{N}-\mathrm{M}-\mathrm{N}$ chains. The presence of spatially extended 

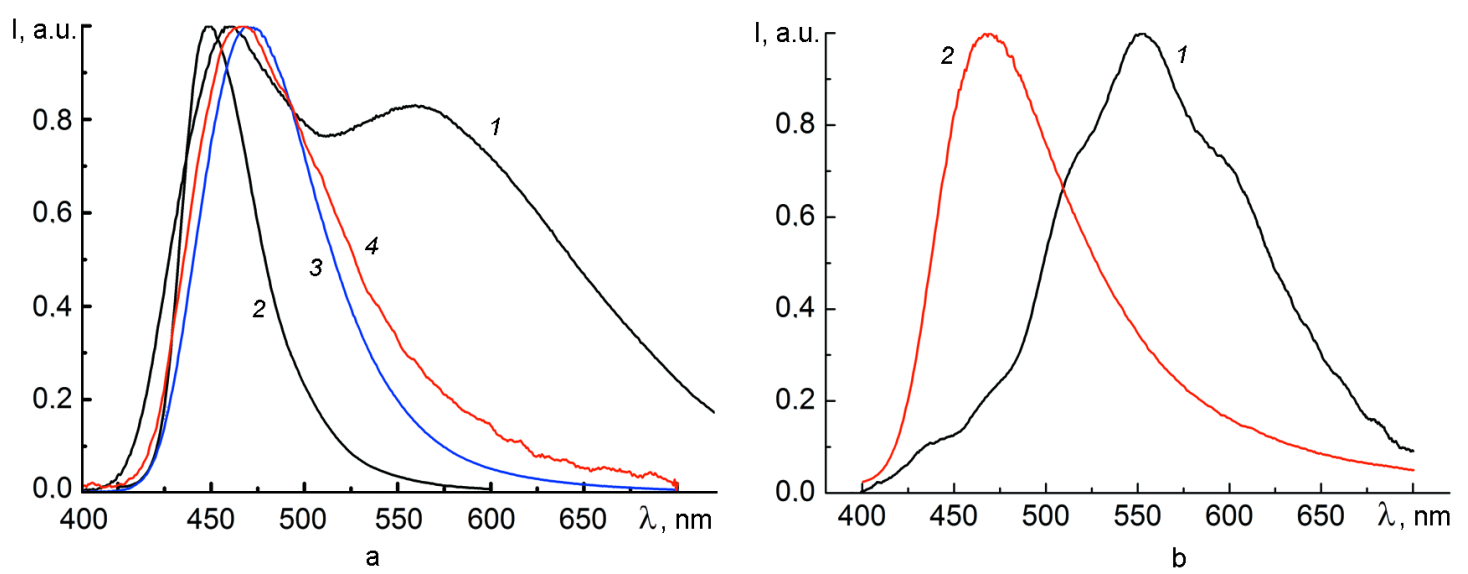

Fig. 2(a). EL spectrum of the device 1 ITO/PTA/NPD/Zn(PSA-BTZ) $2 / A l: C a(1)$; PL spectrum of $\mathrm{Zn}(\mathrm{PSA}-\mathrm{BTZ})_{2}$ powder (2); EL spectrum of the device $3 \mathrm{ITO} / \mathrm{PTA} / \mathrm{NPD} / \mathrm{CBP} / \mathrm{Zn}(\mathrm{PSA}-\mathrm{BTZ})_{2} / \mathrm{Al}: \mathrm{Ca}$ (3); EL spectrum of the device 5 ITO/PEDOT:PSS/Zn(PSA-BTZ) $2 / \mathrm{Al}: \mathrm{Ca}$ (4) (b): EL spectrum of the device 2 ITO/PTA/Zn(PSA-BTZ)2/AICa (1); EL spectrum of the device 4 ITO/PTA/CBP/Zn(PSA$\mathrm{BTZ})_{2} / \mathrm{AlCa}(2)$.

electron-rich amine segment in zinc complex molecule can enhance its ability of intermolecular interactions with the molecules of hole-transporting layer and hence magnify the possibility of exciplex forming.

\section{Experimental}

Electroluminescence was observed for the layered structures containing the transparent anode of indium-tin oxide (ITO), organic hole-transporting layer, luminescence layer of one of the studied complexes and the metallic cathode of $\mathrm{Al}: \mathrm{Ca}(5 \%)$ alloy. The hole-transporting materials used were triaryl derivatives - well known NPD and the oligomer of triphenylamine PTA [22]. Carbazol derivatives CBP and PEDOT:PSS were also used for forming the hole-transporting layer. Structures of these compounds are shown in Fig. 1. All the materials are characterized by blue PL 450-470 nm [18-21]. Zinc complexes and PTA were synthesized as described elsewhere [18-22]. NPD, CBP and PEDON:PSS were supplied by Aldrich. All organic layers in the OLED devices (except PTA and PEDOT:PSS) were prepared by vacuum evaporation. PTA and PEDOT:PSS were spin casted from toluene and aqueous solutions, respectively. EL and PL spectra were measured with the Ocean Optics fiber optics spectrometers QE65000 or PC1000. LED with $\lambda=370 \mathrm{~nm}$ was used to excite the PL.

We have prepared and measured EL spectra of the following OLED devices based on zinc complexes with sulphanylamino-substituted ligands:
Device 1: ITO/PTA/NPD/Zn(PSA-BTZ) $2 / A l: C a ;$ Device 2: ITO/PTA/Zn(PSA-BTZ) $2 / \mathrm{AlCa}(1)$; Device 3: ITO/PTA/NPD/CBP/Zn(PSA-BTZ) $2 /$ Al:Ca;

Device 4: ITO/PTA/CBP/Zn(PSA-BTZ) $2 / \mathrm{AlCa}$

Device 5: ITO/PEDOT:PSS/Zn(PSA-BTZ) $2 /$ Al:Ca;

Device 6: ITO/PTA/NPD/Zn(TSA-BTZ) $2 / \mathrm{Al}: \mathrm{Ca}$; Device 7: ITO/PTA/Zn(TSA-BTZ) $2 / A l: C a ;$

Device 8: ITO/PTA/NPD/Zn(POPS-BTZ) $)_{2} /$ Al:Ca;

Device 9: ITO/PTA/NPD/CBP /Zn(POPS$\mathrm{BTZ})_{2} / \mathrm{Al}: \mathrm{Ca}$;

Device 10: ITO/PTA/NPD/Zn(DFP-SAMQ) $)_{2} /$ AlCa;

Device 11: ITO/PTA/Zn(DFP-SAMQ) $2 /$ AICa.

In some devices, both PTA and NPD deposited in succession were used as materials for the hole-transporting layers. In any case, EL spectrum of the device is determined by that hole-transporting material which is in contact with zinc complex. The devices typically are characterized by bias voltages of light appearance of about 2.5$3 \mathrm{~V}$ and brightness of the order $10^{3} \mathrm{~cd} / \mathrm{m}^{2}$ at $10 \mathrm{~V}$.

\section{Results and discussion}

EL spectra of OLEDs based on $\mathrm{Zn}(P S A-B T Z)_{2}$. Fig. 2 shows the EL spectra of Zn(PSA-BTZ) in two electroluminescence devices: device 1 ITO/PTA/NPD/Zn(PSA-BTZ) $2 /$ Al:Ca (Fig. 2a, curve 1) and device 2 ITO/PTA/Zn(PSA$\mathrm{BTZ})_{2} / \mathrm{AlCa}$ (Fig. 2b, curve 1). For comparison, curve 2 in Fig. 2a shows the PL spectrum of $\mathrm{Zn}(\mathrm{PSA}-\mathrm{BTZ})_{2}$ powder. The EL spec- 

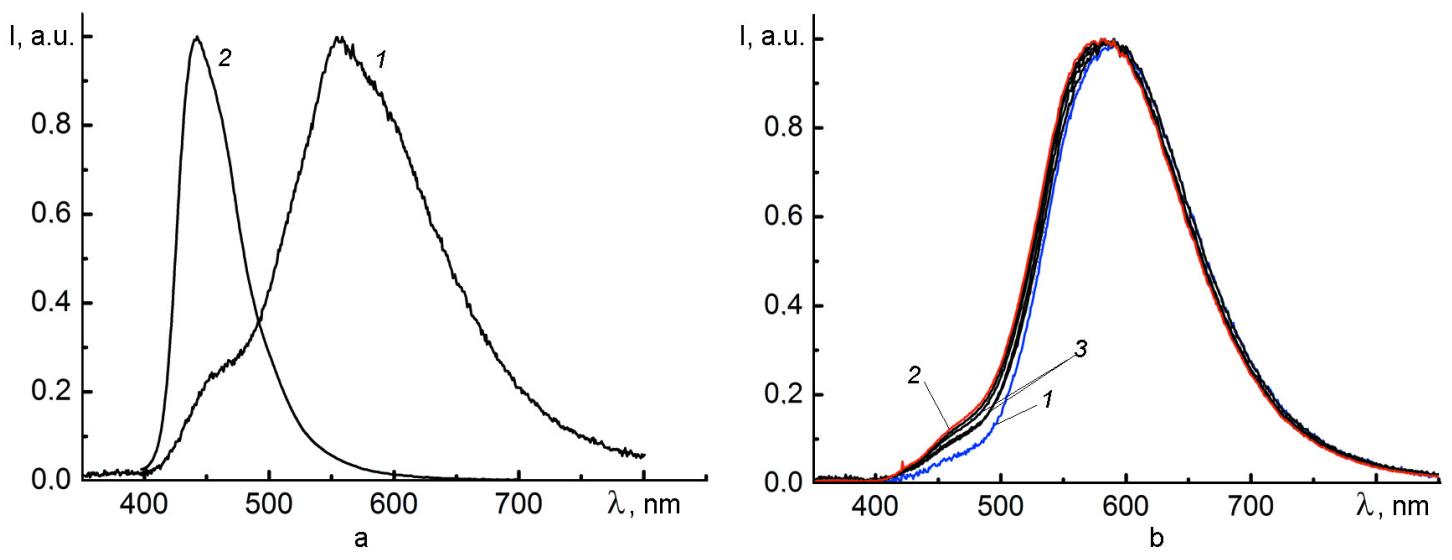

Fig. 3. (a) - Normalized EL spectrum of the device 6 ITO/PTA/NPD/Zn(TSA-BTZ) $2 /$ Al:Ca (1) and PL spectrum of $\mathrm{Zn}(\mathrm{TSA}-\mathrm{BTZ})_{2}$ powder (2);

(b) - Normalized EL spectra of the device 7 ITO/PTA/Zn(TSA-BTZ) $2 /$ Al:Ca for bias voltages $3.5 \mathrm{~V}$ (curve1), 4.0, 4.5, 5.0, 5.5 V (curves 2) and 6.0 V (curve 3 ).

trum of the device 1 contains two bands with maxima at 460 and $560 \mathrm{~nm}$. Maximum of the first band is close to that of $\mathrm{PL}$ peak of $\mathrm{Zn}(\mathrm{PSA}-\mathrm{BTZ})_{2}$ powder at $450 \mathrm{~nm}$ and may be attributed to the intrinsic luminescence of $\mathrm{Zn}(\mathrm{PSA}-\mathrm{BTZ})_{2}$. The second peak may be probably explained by exciplex formation between NPD and Zn(PSA-BTZ) 2 . For the device 2 , the $\mathrm{EL}$ spectrum exhibits only wide band with maximum at $553 \mathrm{~nm}$ which may be attributed to exciplex formation between PTA and $\mathrm{Zn}(\mathrm{PSA}-\mathrm{BTZ})_{2}$.

Exciplex can be formed between the ground state of a donor molecule and the excited state of an acceptor molecule [7]. In our case a donor molecule is presented by NPD or PTA and an acceptor molecule by $\mathrm{Zn}(\mathrm{PSA}-\mathrm{BTZ})_{2}$ complex. Exciplex band corresponds to the transition from the excited state of the acceptor and the ground state of the donor and has lower transition energy compared to the intrinsic emission band corresponding to the transition between the excited and ground state of the acceptor molecule [7].

Combination of narrow intrinsic band and wide exciplex band gives very wide emission spread over the whole visible spectrum which is a way to obtain white light emitting diodes [7, 14-17, 19-21]. For the device 1 , the CIE chromaticity coordinates are $x=0.31, y=0.34$ which is close to that of white light $(x=0.33, y=0.33)$.

Elimination of exciplex emission for the devices based on $\mathrm{Zn}(P S A-B T Z)_{2}$.

To prove the exciplex origin of the long wavelength $\mathrm{EL}$, we have fabricated several control devices in which the long-wave EL bands are eliminated. One of the methods for preventing exciplex emission is the insertion of an additional layer between the hole-transporting and electron-transporting materials [9, 10, 12, 13]. CBP is considered as one of the materials appropriate for such layers [10]. We have fabricated two control devices with CBP as intermediate layer: ITO $/ \mathrm{PTA} / \mathrm{NPD} / \mathrm{CBP} / \mathrm{Zn}(\mathrm{PSA}-\mathrm{BTZ})_{2} / \mathrm{Al}: \mathrm{Ca}$

(device 3) and ITO/PTA/CBP/Zn(PSA$\mathrm{BTZ})_{2} / \mathrm{AlCa}$ (device 4). Fig. 2 shows the EL spectra of the devices 3 and 4 (Fig. 2a, curve 3 and Fig. 3 b, curve 2 , respectively). In both cases, the EL spectra contain no wide band around $560 \mathrm{~nm}$ and exhibit only one band in blue region with maximum at $471 \mathrm{~nm}$ (device 3) and $469 \mathrm{~nm}$ (device 4) which may be attributed mainly to the intrinsic emission of $\mathrm{Zn}(\mathrm{PSA}-\mathrm{BTZ})_{2}$ complex. Similar result on eliminating the exciplex EL by introducing the intermediate CBP layer is described below for $\mathrm{Zn}(\mathrm{POPS}-\mathrm{BTZ})_{2}$ based OLEDs.

It should be noted that NPD and PTA as well as many other materials usually used to form the hole-transporting layer are the derivatives of triarylamines. One may suppose that the interaction of nitrogen atoms in amino groups of the hole-transporting molecules and amino groups of zinc complexes (due to their spatial overlap) determines the exciplex formation in the studied systems. Evidence in favor of this supposition comes from our results on using other materials for hole-transporting layers different from triarylamine derivatives. Curve 4 of Fig. 2a shows the EL spectrum of the device ITO/PEDOT:PSS/Zn(PSA-BTZ) $2 / \mathrm{Al}: \mathrm{Ca} \quad$ (de- 
vice 5) where the hole-transporting layer is presented by PEDOT:PSS, a hole injecting and transporting material which does not contain nitrogen atoms at all. This spectrum does not contain a wide band around $560 \mathrm{~nm}$ and exhibits only one band with maximum at $466 \mathrm{~nm}$ which is close to $\mathrm{Zn}(\mathrm{PSA}-\mathrm{BTZ})_{2}$ powder PL band (450 $\mathrm{nm}$ ) and may be attributed mainly to the intrinsic emission of $\mathrm{Zn}(\mathrm{PSA}-\mathrm{BTZ})_{2}$ complex. One may suppose that the formation of exciplex in this case is suppressed by the absence of nitrogen atoms in the hole-transporting layers.

Commonly, the reason of preventing exciplex emission by changing the hole-transporting material is argued to be the relation between energy levels of donor and acceptor molecules. Materials like CBP with low HOMO (highest occupied molecular orbital) energy level are considered as appropriate ones [9, 10, 12, 13]. Really, the HOMO level of CBP is 6.1-6.3 eV below vacuum level [23-25] which is appreciably lower than that of NPD $(5.2-5.7 \mathrm{eV}[24,26,27])$. On the other hand, highest occupied energy level of PEDOT:PSS is $5.2 \mathrm{eV}$ below vacuum level [28] which does not differ from that of NPD. So, the fact that NPD produce exciplexes with the studied complexes and CBP and PEDOT:PSS do not may be explained not only by positions of energy levels but also by other reasons. Good spatial overlap of donor and acceptor molecular orbitals seems to be one of the most important factors promoting the formation of exciplexes.

From this point of view, molecules with amino-groups are most appropriate for exciplex formation because of high electron density at nitrogen atoms. Zinc complexes studied in the present work contain aminogroups bonded to metal atom and produce exciplexes in pair with triarylamine molecules NPD and PTA. Note that the analogs of our complexes containing oxygen atom bonded to metal such as $M_{3}, Z n q_{2}$, $\mathrm{Zn}(\mathrm{BTZ})_{2}$ do not exhibit exciplexes in their EL spectra when triarylamine hole-transporting materials like NPD or TPD are used [1-6]. At the same time, the derivatives of $\mathrm{Alq}_{3}$ containing amino-groups bonded to quinoline species exhibit EL exciplex bands for the devices with NPD [10].

EL spectra of OLEDs based on $Z n(T S A-B T Z)_{2}$

Fig. 3 shows the EL spectra of $\mathrm{Zn}(\mathrm{TSA}-$ $\mathrm{BTZ}_{2}$ in two electroluminescence devices: device 6 ITO/PTA/NPD/Zn(TSA-BTZ) $2 / \mathrm{Al}: \mathrm{Ca}$ (Fig. 3a) and device 7 ITO/PTA/Zn(TSA$\mathrm{BTZ})_{2} / \mathrm{AlCa}$ (Fig. 3b). In both cases, inten-

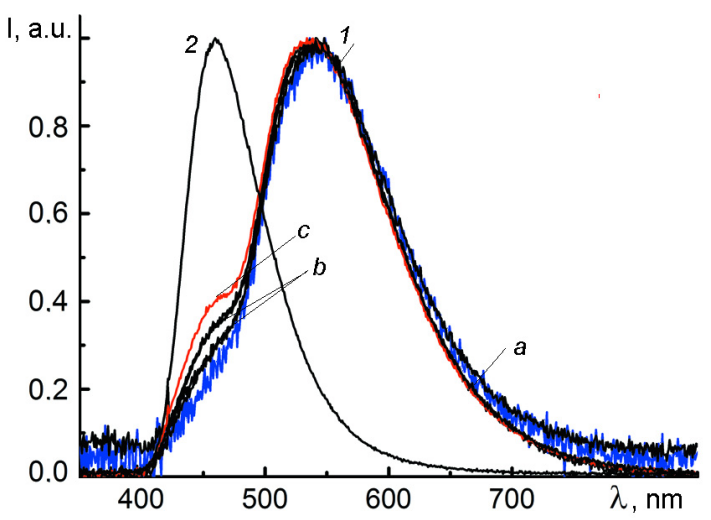

Fig. 4(a). Normalized EL spectra of the device 8 ITO/PTA/NPD/Zn(POPS-BTZ) $)_{2} / \mathrm{Al}: \mathrm{Ca}$ : 1 - for bias voltages $4.0 \mathrm{~V}$ ( $a$ curve), 4.5, $5.0,5.5 \mathrm{~V}$ ( $b$ curves) and $6.0 \mathrm{~V}$ ( $c$ curve); 2 - EL spectrum of the device 9 ITO/PTA/NPD/CBP/Zn(POPS-BTZ) 2 /Al:Ca $\lambda_{\text {max }}=460 \mathrm{~nm}$ (intrinsic emission).

sive exciplex EL bands are observed in yellow region with maxima around $585 \mathrm{~nm}$. Only weak shoulder in the region of intrinsic $\mathrm{Zn}(\mathrm{TSA}-\mathrm{BTZ})_{2}$ emission at about $460 \mathrm{~nm}$ is observed. For the device 7, the EL spectra are shown for different bias voltages from $3.5 \mathrm{~V}$ to $6.0 \mathrm{~V}$. A small continuous growth of intrinsic emission relative intensity is observed. A small blue shift of exciplex band maximum from $585 \mathrm{~nm}$ at $3.5 \mathrm{~V}$ to $575 \mathrm{~nm}$ at $6.0 \mathrm{~V}$ is also observed. This is in contrast with previously reported strong dependence of exciplex bands positions on bias voltages [11].

EL spectra of OLEDs based on Zn(POPS-BTZ) 2

Fig. 4 shows the EL spectra of Zn(POPS$\mathrm{BTZ})_{2}$ in the device ITO/PTA/NPD/Zn(POPSBTZ)2/Al:Ca (device 8). Strong exciplex band in green region with the maximum at about $540 \mathrm{~nm}$ and shoulder at about $460 \mathrm{~nm}$ due to intrinsic emission of $\mathrm{Zn}(\mathrm{POPS}-\mathrm{BTZ})_{2}$ are observed. The EL spectra are shown for different bias voltages from $4.0 \mathrm{~V}$ to $6.0 \mathrm{~V}$. A small continuous growth of intrinsic emission relative intensity and a small blue shift of exciplex band maximum from $545 \mathrm{~nm}$ at $4.0 \mathrm{~V}$ to $535 \mathrm{~nm}$ at $6.0 \mathrm{~V}$ are also observed.

Similar to the devices based on Zn(PSA$B T Z)_{2}$ the exciplex band can be eliminated by introducing the intermediate layer of CBP between NPD and Zn(POPS-BTZ)2. The EL spectrum of the device ITO/PTA/NPD/CBP/Zn(POPS$\mathrm{BTZ})_{2} / \mathrm{Al}: \mathrm{Ca}$ (device 9) is shown in Fig. 4 (curve 2). The exciplex band in the region of $540 \mathrm{~nm}$ is absent and only the intrinsic 


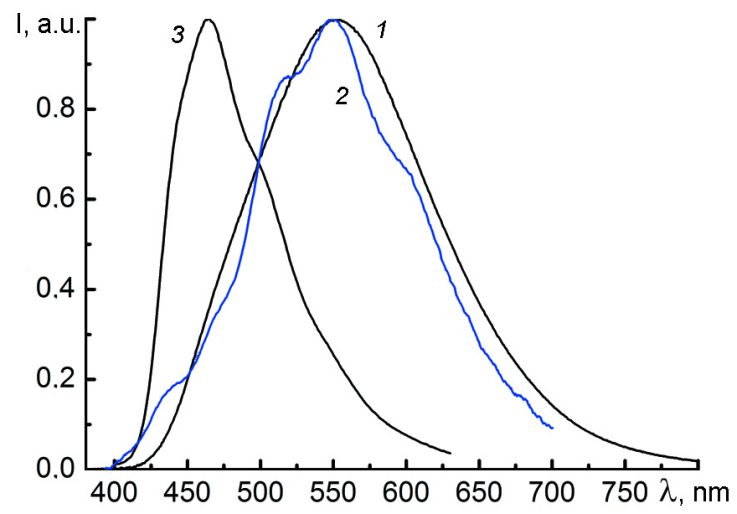

Fig. 5. EL spectra of the devices 10 ITO/PTA/NPD/Zn(DFP-SAMQ) $)_{2} / \mathrm{AICa}(1)$ and 11 ITO/PTA/Zn(DFP-SAMQ) $)_{2} /$ AICa (2) and PL of $\mathrm{Zn}(\mathrm{DFP}-\mathrm{SAMQ})_{2}$ powder (3).

emission of $\mathrm{Zn}(\mathrm{POPS}-\mathrm{BTZ})_{2}$ at $\lambda_{\max }=$ $460 \mathrm{~nm}$ is observed.

EL spectra of OLEDs based on Zn(DFP-SAMQ) 2

Fig. 5 shows the EL spectra of Zn(DFPSAMQ $)_{2}$ in the devices ITO/PTA/NPD/Zn(DFP$\mathrm{SAMQ})_{2} / \mathrm{AICa}$ (device 10, curve 1) and ITO/PTA/Zn(DFP-SAMQ) $2 /$ AlCa (device 11, curve 2). For comparison, the PL spectrum of $\mathrm{Zn}(\mathrm{DFP}-\mathrm{SAMQ})_{2}$ powder is shown (curve 3). Exciplex bands with maxima at about $560 \mathrm{~nm}$ are observed in the EL spectra, no intrinsic emission is observed.

\section{Conclusions}

The novel zinc-chelate complexes of sulphanylamino-substituted quinolines and benzothiazoles are proper materials for OLEDs with efficient exciplex emission giving rise to white OLEDs and OLEDs of different colors including blue, green and yellow. Exciplex emission can also be observed in PL spectra of the films containing blends of zinc complex and hole-transporting material. Material of hole-transporting layer is crucial for efficiency of exciplex formation. Triarylamine derivatives seem to be the most proper materials for exciplex formation. This may be due not only to positions of energy levels but also to good spatial overlap and high electron density on aminogroups of both zinc complex and triarylamine derivatives.

\section{References}

1. P.Burrows, Z.Shen, V.Bulovic et al., J.Appl. Phys., 79, 7991 (1996).
2. P.Burrows, L.Sapochak, D.McCarty et al., Appl.Phys. Lett., 64, 2718 (1994).

3. C.Tang, S.VanSlyke, Appl.Phys.Lett., 51, 913 (1987).

4. Y.Hamada, T.Sano, M.Fujita et al., Jpn.J. Appl. Phys. Part 2 - Lett., 32, L514 (1993).

5. Y.Hamada, T.Sang, H.Fujii et al., Jpn.J.Appl. Phys. Part 2 - Lett., 35, L1339 (1996).

6. H.Tanaka, S.Tokito, Y.Taga et al., J. Mater. Chem., 8, 1999 (1998).

7. J.Thompson, R.I.R.Blyth, M.Mazzeo et al., Appl.Phys. Lett., 79, 560 (2001).

8. M.Cocchi, D.Virgili, G.Giro et al., Appl.Phys. Lett., 80, 2401 (2002).

9. W.M.Su, W.L.Li, Q.Xin et al., Appl.Phys. Lett., 91, (2007).

10. S.H.Liao, J.R.Shiu, S.W.Liu et al., J.Amer Chem. Soc., 131, 763 (2009).

11. K.Itano, H.Ogawa, Y.Shirota, Appl. Phys. Lett., 72, 636 (1998).

12. G.Li, C.H.Kim, Z.Zhou et al., Appl. Phys. Lett., 88, ??? (2006).

13. T.Noda, H.Ogawa, Y.Shirota, Adv, Mater., 11, 283 (1999).

14. Y.Liu, J.H.Guo, H.D.Zhang et al., Angew. Chem.-Intern.Ed., 41, 182 (2002).

15. C.I.Chao, S.A.Chen, Appl. Phys. Lett., 73, 426 (1998).

16. Q.X.Tong, S.L.Lai, M.Y.Chan et al., Appl. Phys. Lett., 91, (2007).

17. M.T.Li, W.L.Li, L.L.Chen et al., Appl. Phys. Lett., 88, (2006).

18. I.K.Yakushchenko, M.G.Kaplunov, S.S.Krasnikova et al., Zh.Koord.Khim., 35, 312 (2009).

19. M.G.Kaplunov, I.K.Yakushchenko, S.S.Krasnikova et al., Mol. Cryst. Liq. Cryst., 497, 543 (2008).

20. M.G.Kaplunov, I.K.Yakushchenko, S.S.Krasnikova et al., High Energy Chem., 42, 563 (2008).

21. S.Krasnikova, M.Kaplunov, I.Yakushchenko, High Energy Chem., 43, 536 (2009).

22. I.K.Yakushchenko, M.G.Kaplunov, O.N.Efimov et al., Phys. Chem. Chem. Phys., 1, 1783 (1999).

23. I.G.Hill, A.Rajagopal, and A.Kahn, J. Appl. Phys., 84, 3236 (1998).

24. M.A.Baldo, S.Lamansky, P.E.Burrows et al., Appl. Phys. Lett., 75, 4 (1999).

25. V.Adamovich, J.Brooks, A.Tamayo et al., New J. Chem., 26, 1171 (2002).

26. Wolfgang Brutting, Stefan Berleb, A.G.Muckl, Organ. Electron., 2, 1 (2001).

27. M.T.Lee, C.K.Yen, W.P.Yang et al., Org. Lett., 6, 1241 (2004).

28. J.Y.Kim, M.Kim, H.M.Kim et al., Opt. Mater., 21, 147 (2003). 


\title{
Ексиплексні спектри електролюмінесценції нових органічних матеріалів на основі цинкових комплексів сульфаніламінозаміщених лігандів
}

\author{
С.Л. Нікітенко, С.С.Краснікова, М. Г.Каплунов, \\ І.К.Якущенко
}

\begin{abstract}
Досліджено спектри електролюмінесцентних пристроїв, заснованих на нових комплексах амінозаміщених бензотіазолів і хінолінів, які містять C-N-M-N ланцюги в їх хелатних циклах. Виявлено сильні эксиплексні смуги у жовто-зеленій області (540-590 нм) спектра при взаємодії збуджених станів комплексу цинку і молекули триариламіну дірково-транспортного шару. Для деяких пристроїв, крім ексиплексної смуги, також спостерігається власна смуга люмінесценції в області 460 нм, що приводить до майже білого кольору випромінювання пристрою. Ексиплексна смуга може бути прибрана, якщо матеріал дірково-транспортного шару не $\epsilon$ похідним триариламіну.
\end{abstract}

